\title{
ВПЛИВ МІЖНАРОДНО-ПРАВОВИХ АКТІВ НА КОНСТИТУЦІЙНІ ТРАНСФОРМАЦІЇ В ДЕРЖАВАХ-ЧЛЕНАХ ЄВРОПЕЙСЬКОГО СОЮЗУ
}

Анотація. В сучасних умовах глобалізації прослідковуємо посилення інтеграції між державами у різних cферах, у тому числі й у правовій, що супроводжуеться зростанням ролі міжнародного права та його все більш тісному взаємозв'язку з нащіональними галузями права, а найбільше - 3 конституційним правом. Взаємовплив конституційного і міжнародного права, але не єдиним джерелом котрого являється міжнародний договір, що зумовлюе необхідність дослідити питання щодо форм конституціоналізації міжнародноправових актів, набуття окремими з них статусу джерел конституційного права. Прослідковується значна активна розробка правового статусу такого джерела міжнародного права, як імперативні норми Проте крім того в сучасних умовах бачимо формування за допомогою міжнародно-правових інструментів першого позадержавного наднаціонального конституційного права - права ЄС, що є проявом тісного зв'язку та взаємодії конституційного та міжнародного права, формування права ЄС хоч і на основі міжнародного права.

Ключові слова: міжнародно-правові акти, конституційне право, Свропейський Союз, міжнародні договори, система права.

Lepish Natalia, Prots Ivanna Lviv State University of Internal Affairs

\section{IMPACT OF THE INTERNATIONAL LEGAL ACTS ON THE CONSTITUTIONAL TRANSFORMATIONS IN THE MEMBER STATES OF THE EUROPEAN UNION}

Summary. In the current context of globalization, we see the strengthening of integration between states in various fields, including legal, which is accompanied by the growing role of international law and its ever closer relationship with national branches of law, and most of all - with constitutional law. Interaction of constitutional and international law, the main but not the only source of which is an international treaty, which necessitates the study of forms of constitutionalization of international legal acts, the acquisition of some of them the status of sources of constitutional law. There is a significant active development of the legal status of such a source of international law as the imperative rules of international law, which by their nature are also constitutional. In addition, in modern conditions we see the formation of international legal instruments of the first non-state supranational constitutional law - European Union law, which is a manifestation of close connection and interaction of constitutional and international law, the formation of European Union law, albeit on the basis of international law. quality of the new legal system, which has a constitutional character. The activity of the European Court of Human Rights on the European Convention for the Protection of Human Rights and Fundamental Freedoms of 1950 is becoming increasingly important in Europe, and its role in shaping the constitutional law of nation states on the basis of common constitutional values is growing. Therefore, international law in its modern form is not limited to "traditional" international treaties, but it is isolated from national legal systems, but on the contrary, there is an increasing integration. After considering the formation and formation of supranational constitutional law at the EU level, it is necessary to investigate the impact of EU law on the constitutional law of individual member states. We have already noted that the recognition of the existence of EU constitutional law is connected, first of all, with a certain restriction of the sovereignty of states in favor of the Union, which created the conditions for its activity within the framework of the institutional mechanism.

Keywords: International legal acts, constitutional law, European Union, international agreements, system of law.

$\Pi$ остановка проблеми. Визнання існування конституційного права ЄC пов'язано в першу чергу із певним обмеженням суверенітету держав на користь Союзу, що створило умови для його діяльності в рамках інституційного механізму. Суд $\mathrm{CC}$, визнавши в своїх рішеннях принципи верховенства права $\mathrm{CC}$, а також існування нового правопорядку остаточно дав нам зрозуміти про те, що в рамках $\mathrm{CC}$ не можна говорити про якусь традиційну міжнародну організащію. Зрештою, конституційні трансформації в праві держав-членів краще це ілюструють, а тому потрібно розглянути такі на прикладі деяких країн.

Аналіз останніх досліджень і публікацій. Нормативну основу дослідження становлять Конституція України та чинне законодавство України з інтеграції України до Європейського
Союзу, правові акти ЄС, конституції країн-членів $\mathrm{CC}$, міжнародні акти.

Науково-емпіричну основу дослідження становлять матеріали правозастосовчої практики Суду ЄC, органів конституційної юстиції країнчленів Свропейського Союзу, а також практика Конститущійного Суду України щодо застосування норм европейського законодавства при здійсненні конституційного судочинства, наукові праці европейських учених мовами оригіналу.

Мета статті. Здійснити аналіз впливу міжнародно-правових актів на конституційні трансформації в державах-членах Європейського Союзу.

Виклад основного матеріалу. Почнемо з такої країни як Великобританія, як держави, котра не мае класичної писаної Конституції. Проблеми внесення змін до конституційного законодавства Великобританії пов'язані із док- 
триною парламентського суверенітету, а саме переконання, що «не існуе жодних правових обмежень для парламенту Сполученого Королівства та він має право приймати або скасовувати будь-який закон. Таким чином, жодна особа чи орган не має права нехтувати цим правилом». Приєднання Великобританії до Європейських співтовариств зумовило необхідність прийняття European Communities Act 1972, що регулював питання дії права ЄС. Так, в пункті 2.1 даного Акта вказано, що «всі права, повноваження, відповідальність, зобов'язання та обмеження, котрі час від часу створюються виникають 3 договорів, та усі засоби захисту і правила процедури, які час від часу виникають 3 договорів та з'являються на їх основі, мають пряму силу і повинні застосовуватися в Сполученому Королівстві без подальшого введення в дію, повинні бути визнані та діяти, їм необхідно слідувати і відповідним чином здійснювати». Таким чином, завдяки цим положенням принцип прямої дії права ЄС знайшов своє втілення в конституційному акті Великої Британії. Що цікаво, питання, чи є можливим подальше існування доктрини парламентського суверенітету в Сполученому Королівстві стало предметом розгляду справ R (Factortame Ltd) v Secretary of State for Transport, де було вирішено, що «якщо права, передбачені правом Співтовариств $\epsilon$, прямо застосовуються на користь сторони, подала апелящію, ці права превалюють над національним законодавством, суперечить їм, навіть якщо воно було прийнято пізніше». Цікаво, що в одному з рішень, було відзначено, що "хоча верховенство в рамках Свропейських Співтовариств права Співтовариств над національним правом держав-членів не завжди було притаманне E.E.C. Treaty (Римському Договору, зараз діє як ДФЕС), але воно було чітко визначено в практищі Свропейського Суду Справедливості (тобто Суд ЄС) задовго до приеднання Сполученого Королівства до спільнот. Таким чином, то обмеження суверенітету парламенту, яке було введено European Communities Act 1972 року було повністю добровільним. Згідно з умовами цього Акта завжди було зрозуміло, що обов'язком суду Сполученого Королівства при прийнятті рішень було нехтування будь нормою національного права, якщо вона суперечила прямо застосовуеться праву спільнот. Аналогічним чином, коли рішення Свропейського Суду Справедливості проявляли певні сфрери правового регулювання, де статутне право не імплементувала належним чином директиви, Парламент завжди лояльно брав на себе зобов'язання зробити швидко відповідні поправки. Дискусії про існування парламентської суверенітету в таких умовах в британських умовах призвели врешті-решт до прийняття European Union Act 2011 року, ст. 18 якого передбачає, що «безпосередньо застосовується або чинне право ЄС визнаються і діють в праві Сполученого Королівства тільки в силу Акту Парламенту» [1].

За Конституцією Німеччини, правовою основою для членства в ЄС виступае перш за все ст. 24 Конституції, котра визначає, що «Федерація може передати суверенні повноваження міжнародної організації шляхом прийняття закону». Однак безпосередньо питань, пов'язаних 3 член- ством в Свропейському Союзі присвячена ст. 23 ч. 1 якої визначає, що «з метою побудови об'єднаної Свропи Федеративна Республіка Німеччина бере участь у розвитку Свропейського Союзу, що бере на себе відповідальність поважати демократичні, соціальні та федеральні принципи, принцип верховенства права, принцип субсидіарності, і який гарантуе такий рівень захисту основних прав, зміст яких відповідає тому, який закріплений в Основному Законі». Також ця стаття встановлює, що Бундестаг і Бундесрат має право звернутися до Суду СС у разі порушення законодавчим актом ЄС принципу субсидіарності (23 (1a)) Бундестаг, а також Землі (через Бундесрат) беруть участь у справах, пов'язаних з Свропейським Союзом (23 (2)) і ряд інших. Ряд положень міститься і в інших статтях, наприклад, ст. 28 передбачає, що особи, котрі мають громадянство будь-якої держави-члена ЄС мають право обирати та бути обраними на місцевих виборах відповідно до права ЄС; ст. 45 передбачає створення Комітету у справах ЄС; ст. 88 передбачає можливість передачі окремих повноважень від Федерального Банку до Європейського Центрального Банку та деякі інші. Таким чином, аналіз Конституції ФРН дозволяе стверджувати, що в ній закріплено ряд положень, пов'язаних із діяльністю СС, i вона зазнала певних змін для того, щоб відповідати положень права ЄС. Як бачимо, в даній Конституції теж згадуеться можливість передачі суверенних повноважень. Деякі питання дії права СС в $\mathrm{Hi}-$ меччині викликали розгляд Конституційним Судом ФРН окремих справ. Так, у справі Solange I в 1974 рощі Суд визнав, що «поки визнання прав людини Свропейським Співтовариством не досягло того рівня, який є забезпечений нормами Конституції, німецькі суди мають право ставити питання про конституційність вторинного права Співтовариств», що могло потенційно привести до невизнання дії права Співтовариств. Згодом, уже в 1986 році у справі Solange II Конституційний Суд ФРН зазначив, що «поки Європейські Співтовариства, зокрема європейське прецедентне право, в загальному забезпечують ефективний захист основних прав ... і поки право Співтовариств можна розглядати змістовно аналогічним захисту основних прав, потрібно Конституцією, і поки воно охороняе необхідний обсяг основних прав, Федеральний Конституційний Суд більше не поширювати свою юрисдикцію на вирішення питань про можливість застосування вторинного права ЄС...» [2, с. 120]. Таким чином, в даному рішенні Федеральний Конституційний Суд залишив потенщійну можливість для конституційного контролю, єдиним критеріем для котрого може вважатися більший рівень захисту основних прав Конституції, визнаючи за нею пріоритет у випадках недостатності захисту прав законодавством ЄC. Однак уже в 1993 році в Maastricht Judgment Федеральний Конституційний Суд вирішив, що «акти публічної влади наднаціональної організації, яка є окремою від державної влади державчленів ... можуть вплинути на гарантії, передбачені Основним Законом, і обов'язки Федерального Конституційного Суду, які включають в себе захист основних прав в Німеччині, і не тільки по німецьких урядових установ. Однак Федеральний Конституційний Суд здійснюе свою юрисдикцію 
щодо застосування похідного права Співтовариств в Німеччині «в кооперації» з Свропейським Судом Справедливості».

Конституція Італії також містить деякі положення, пов'язані з членством в Свропейському Союзі. Основою для цього е стаття 11 Конституції, згідно з якою «Італія погоджується на умовах рівності 3 іншими державами, 3 обмеженнями суверенітету, які можуть знадобитися для забезпечення світового порядку, забезпечуе мир і справедливість між державами». Містяться також і норми, що стосуються вже безпосередньо взаємодії з СС - загальні державні органи, відповідно до права СС, повинні забезпечити збалансовані бюджети і стабільність державного боргу (ч. 1 ст. 97); законодавча влада покладається на державу i регіони відповідно до Конституції і з обмеженнями, що випливають із законодавства СC і міжнародних зобов'язань (ч. 1 ст. 117) і деякі інші. М. Ізенбер, аналізуючи досвід Італії щодо конституційних змін в цій державі у зв'язку з членством в Союзі приходить до висновку, що питання співвідношення права СС з італійським правом стали предметом розгляду Конституційного Суду. Так, в даній роботі стверджується, що «в справі Frontini в 1973 році італійський Конституційний Суд визнав Верховенство права СС, хоча і 3 певними обмеженнями ... Конституційний Суд визнав, що право Співтовариств є відокремленим від міжнародного права і внутрішньодержавного права держав-членів і визнав, що право Співтовариств і національне право є «автономними і певними правовими системами, хоча і скоординованими відповідно до розподілу влади, встановленого Договорами». Таким чином, в цьому рішенні теж визначається правова природа правової системи ЄС. Згодом, вказуе автор, «італійський Конституційний Суд визнав, що він буде продовжувати здійснювати нагляд за діяльністю органів Союзу для того, щоб переконатися у відсутності порушень основоположних прав або основних принципів італійського конституційного правопорядку». Отже, можемо спостерігати схожу ситуацію, як і в Німеччині, коли незважаючи на визнання верховенства права ЄС і внесення змін до Конституції, Конституційний Суд все ще залишив за собою потенційну можливість здійснювати нагляд за діяльністю органів СС, якщо вони будуть порушувати основоположні права або основи конституційного правопорядку. Така практика як італійського, так і німецького Конституційного Суду наштовхує на думку, що визнання верховенства права ЄС фонкціональний характер, і воно $є$ допустимим до того моменту, поки не порушує основні конституційні гарантії, встановлені національним правом. Зрештою, це цілком відповідає сучасному розумінню права, коли основним $\epsilon$ едрективний захист прав людини, дозволяє при необхідності відходити від таких принципів як верховенство права ЄС [3, с. 71].

За Конституцією Франщії, то крім загальної норми ст. 55, згідно з якою належним чином укладені і ратифріковані договори з моменту свого опублікування мають вищу юридичну силу ніж національне право, вона містить окремий розділ XV «Про Свропейський Союз». У ньому містяться норми, що передбачають підстави участі Франції в Союз. Зокрема, «Республіка бере участь в Свро- пейському Союзі, створеному державами, вільно вирішили здійснювати частину своїх повноважень в загальному, в силу Договору про Свропейський Союз та Договору про фрункщіонування Свропейського Союзу, як вони випливають з договору, підписаного в Лісабоні 13 грудня 2007 року» (ст. 88-1; як бачимо, Конституція містить посилання безпосередньо на установчі договори). Також передбачено положення, згідно 3 яким «статути визначають правила, що стосуються Свропейського ордера на арешт згідно актів, прийнятих установами Європейського Союзу» (ст. 88-2). Також передбачено право голосувати на місцевих вибоpax, а також балотуватися на них громадянам Союзу, які проживають у Франції, однак із застереженням, згідно з яким вони не можуть ні займати посаду мера або його заступника, ні брати участь у виборах в Сенат. Умови на участь у виборах громадян СС передбачаються законом (ст. 88-3). Наступні кілька статей стосуються в основному взаємовідносин законодавчої та виконавчої гілок влади 3 органами Свропейського Союзу. Передбачено також обов'язок призначення редерендуму в разі ратифрікації договору про приеднання нових держав до Свропейського Союзу (ст. 88-5). Таким чином, фрранцузька Конституція досить прогресивно вводить в своєму тексті окремий розділ з питань участі в ЄС, на відміну від, наприклад, Конституції ФРН.

Науковщі відзначають, що важливим питання конституційного регулювання є взаємини між національними судами та Свропейським Судом Справедливості, зокрема щодо верховенства права Суду над нащіональним правом. Як бачимо, з аналізу конституційних змін декількох державчленів СС, основні 3 них стосуються можливості передачі суверенних повноважень в міжнародні організації. Також Конституції можуть містити деякі інші положення (наприклад, 3 виборів до органів місцевого самоврядування громадянами іншої держави-члена СC, передбачено установчими договорами, з проаналізованих нами Конституції стає зрозумілим, що це положення теж намагалися відобразити саме на конституційному рівні). Однак за принципом верховенства права ЄC і співвідношення його 3 нащіональним правом, Конституції таких положень не містять. Це пов'язано, перш за все, з тим фрактом, що навіть самі установчі договори не містять положення про верховенство права ЄС (це одне зі спірних положень ще проекту Конституцї для Свропи, не знайшло свого втілення в Лісабонському договорі.

Найзручніший спосіб виглядає думка автора, згідно з якою національні суди, при інших рівних умовах, спрямовані на врегулювання питання верховенства права ЄС таким чином, що тягне за собою найменше порушення конституційного ладу. По суті, їх діяльність в щій сфері зводиться до якомога більш оптимального врегулювання проблемних питань, які виникають. Згодом автор наводить цілком логічний аргумент, що випливає з договірної суті міжнародного права, стверджуючи, що «держави-члени СС (крім шести держав-засновників), приєднуючись до Союзу, прекрасно знали умови членства, в тому числі існування правової системи СС, центральною частиною якої $є$ доктрина верховенства. Для таких держав спроба надалі якимось чином обійти 
норми права СС була б дією, може зашкодити умови договору, з якими вони погодилися шляхом вступу в Союз. Той фракт, що подальші зміни в установчих договорів не торкнулися суті прецедентного права Співтовариств, так само передбачає договірне обгрунтування того, що первинні шість держав також повинні дотримуватися цих норм» [4, с. 45]. На нашу думку, саме в договірній природі Союзу і можна знайти належне обгрунтування доктрині верховенства, і в цій цитаті П. Крейга містяться чіткі обгрунтування на користь цієї думки. Держави-члени добровільно, за допомогою інструментів міжнародного права, шляхом укладення або приєднання до міжнародного договору погодилися на передачу своїх суверенних повноважень 3 окремих питань в Союз для досягнення загальних цілей. Заперечення основоположного правового принцип не лиже міжнародного права, а й права в цілому - pacta suct servanda, призвело б до краху будь-яких сучасних уявлень про право, і є неприпустимим. I механізм виходу з СС дозволяе будь-якій державі здійснити своє волевиявлення і вийти з Союзу в разі незгоди 3 його діяльністю. I хоча держави-члени СС внесли зміни в свої Конституції, щоб уникнути потенційних конфрліктів між національним правом і правом $\mathrm{CC}$, все ж в окремих судових рішеннях, проаналізованих нами вище, можна знайти підтвердження того, що право СС ніяк не може суперечити основоположним конституційним нормам. Зрештою, критерій, виведений в Solange cases, a caме невтручання Федерального Конституційного Суду Німеччини в питанні визнання дії права СС до того моменту, поки воно не суперечить основам конституційного ладу Німеччини, теж пов'язаний 3 договірної правовою природою права ЄC [6, с. 87].

Мабуть нормативне підгрунтя 3 цих питань можна знайти в ст. 4 (2) ДЕС, згідно з якою «Союз поважає рівність держав-членів в рамках даних договорів, а також їх національну ідентичність, властиву їх фрундаментальним структурам, політичним i конституційним, включаючи регіональним і місцевим самоврядуванням. Він поважає їх основні державні фонкції, включаючи територіальну цілісність держави, дотримання прав і порядку і забезпечення національної безпеки. Зокрема, нащіональна безпека залишається у виключній відповідальності державчленів». Як відзначають вчені «ця стаття може розглядатися як об'єднуюча судову практику численних національних конституційних судів про співвідношення національного права і права ЄС. Ця стаття не тільки вимагає поваги до національної конституційної ідентичності, але і з неї можна зрозуміти дозвіл для національних конституційних судів накласти, при певних умовах, конституційні обмеження на примат права ЄC». Цікавий висновок, і хоча це норма і не вказує безпосередньо на таку можливість, а лише кілька декларативно свідчить принцип поваги ЄC до держави та її національної ідентичності, на нашу думку, правова система ЄС демонструе реальне, а не декларативне втілення правових принципів в практику. Це як раз той випадок, коли правовий принцип не залишаеться мертвою декларативною нормою, а реально діє, і саме 3 його положень виводяться інші норми.
I саме тому, автори дослідження пропонують вивести ст. 4 (2) ДЕС наступні положення:

1) ця стаття є проявом европейського складеного (composite) конституціоналізму в якому право ЄC і національне конституційне право тісно взаємодіють у визначенні національної ідентичності;

2) принципи національного конституційного права, $є$ захищені національними конституційними судами є парадигмою щодо з'ясування змісту нащіональної ідентичності;

3) національна ідентичність, однак, не користуеться абсолютним захистом відповідно до права ЄC, повинна бути збалансована, для того, щоб принцип однакового застосування права СС діяв; імплементація цього принципу е завданням як Суду ЄC, так і національних конституційних судів як складових системи складеного конституційного правосуддя;

4) це взаємодія між Судом СС і нащіональними конститущійними судами слід розглядати як механізм поділу влади.

Отже, для вирішення питання хто має владу вирішувати питання про національну ідентичність не має чіткої відповіді, так само як немає своєрідного органу останньої інстанції, який міг би винести рішення. Тому щоб уникнути потенційних конфрліктів можливо в першу чергу завдяки взаємній згодні на співпрацю.

Як бачимо, на нашу думку таке рішення даного питання містить кілька переваг.

Перш за все, це свідчить про відхід від ідеї чистого нормативізму, коли ми не тільки не вирішуємо традиційне юридичне питання «яка ж норма наділяється вищу юридичну силу», а й вважаємо його першочерговим в питанні потенційних протиріч між правом СС і конституційним правом держав членів.

По-друге, дієвість права ЄС свідчить про його практичну спрямованість, позбавлену догматичних уявлень, яка має на меті забезпечити максимальну гарантію прав людини.

По-трете, примат права СC і принцип верховенства конституційних норм держав-членів хоч з першого погляду і повинні суперечити один одному, але не суперечать, і таке тлумачення дається як на доктринальному рівні, так і рівні судовому, що є своєрідною реалізацією концепції «живого права», права динамічного, пристосованого до реальних потреб.

По-четверте, в основу вирішення конфрліктів покладено критерій максимального забезпечення належного рівня захисту прав людини, дозволяе в необхідних випадках відійти від принципу примату права $\mathrm{CC}$, якщо воно суперечить конституційним положенням, які гарантують кращий рівень захисту прав людини [6].

Висновки. Отже, можемо підсумувати, що конституційні-трансрормації в державах-членах ЄС охоплюють собою два основних аспекти. Це введення в національні Конституції положень про можливість певного обмеження суверенітету або його передачі, а також деяких питань, традиційно визначаються на конституційному рівні i регулюються нормами СС, тобто приведення Конституції відповідно до цих норм, а також вирішення питань про співвідношення конституційного права і права ЄC. I якщо висновок про примата права ЄС над звичайним національ- 
ним правом не викликае сумнівів, то за таким над конституційним правом практика пішла по шляху врегулювання цього питання на судовому рівні, не вирішуючи безпосередньо питання про ієрархії правових норм, але втілюючи більш прогресивні і сучасні ідеї за цільовим і фрункціонального призначення права СС, таким чином реалізуючи на практиці і стверджуючи своєрідну дворівневу систему конституційного права - національне і наднащіональне, в їх взаємодії

\section{Список літератури:}

1. Мацькевич М. М. Міжнародні акти з прав і свобод людини і громадянина. М. М. Мацькевич. Правничий вісник Університету "КРОК". 2014. Вип. 19. С. 56-61. URL: http://nbuv.gov.ua/UJRN/Pvuk_2014_19_10

2. Яцишин Н.Г. Теорія і практика застосування чинного вітчизняного та міжнародного законодавства в сучасних умовах : Матеріали Міжнародної науково-практичної конференції (м. Одеса, Україна, 12-13 лютого 2011 р.). Одеса : у 3-х частинах. Одеса : ГО «Причорноморська фундація права», 2011. Ч. 1. С. 120-122.

3. Право Свропейського Союзу : підручник / під ред. В.І. Муравйова. Київ : Юрінком Інтер, 2011. С. $520-527$.

4. Право Європейського Союзу : підручник / під ред. Г. А. Петрова. Вид. 9, змінено і доповнено. Харків : Право, 2019. $442 \mathrm{c}$.

5. Статут Організації Об'єднаних Націй і Статут Міжнародного суду ООН : Статут Міжнародної організації від 26.06.1945 p. URL: https://zakon.rada.gov.ua/laws/show/995_010

6. Криза Європейського Союзу в світлі констітуціоналізаціі міжнародного права (Есе до питання про конституцію Свропи). Юрген Хабермас. Інститут Макса Планка з зарубіжних публічно і міжнародним правом. Дайджест публічне право. Випуск 2 (2013), 1, 1-53. URL: http://dpp.mpil.de/02_2013/art2_1.cfm

\section{References:}

1. Matskevich M.M. (2014) International acts on human and civil rights and freedoms. Rights Bulletin of the University "KROK", vol. 19, pp. 56-61. URL: http://nbuv.gov.ua/UJRN/Pvuk_2014_19_10

2. Yatsyshyn N.H. (2011) Theory and practice of application of the current domestic and international legislation in modern conditions: Proceedings of the International scientific-practical conference (Odessa, Ukraine, February 12-13, 2011). Odessa: in 3 parts. Odessa: NGO "Black Sea Law Foundation", part 1, pp. 120-122.

3. European Union law: a textbook (2011) / ed. V.I. Muravyova. Kyiv: Yurinkom Inter, pp. 520-527.

4. European Union law: textbook (2019) / ed. G.A. Petrov. Vol. 9, changed and reports. Kharkiv: Pravo, 442 p.

5. Charter of the United Nations and the Charter of the International Court of Justice: Charter of the International Organization of June 26, 1945. URL. https://zakon.rada.gov.ua/laws/show/995_010

6. The crisis of the European Union in the light of the constitutionalization of international law (Essays on the Constitution of Europe). Jürgen Habermas. Max Planck Institute for Foreign Public and International Law. Public Law Digest. Issue 2 (2013), 1, 1-53. URL: http://dpp.mpil.de/02_2013/art2_1.cfm 